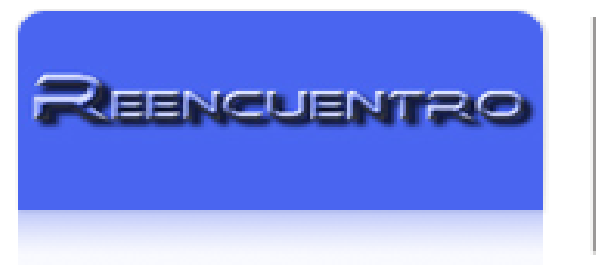

Reencuentro

ISSN: 0188-168X

cuaree@correo.xoc.uam.mx

Universidad Autónoma Metropolitana Unidad Xochimilco

México

Olsen, Johan P.

Democratic government, institutional autonomy and the dynamics of change

Reencuentro, núm. 58, agosto, 2010, pp. 62-77

Universidad Autónoma Metropolitana Unidad Xochimilco

Distrito Federal, México

Available in: http://www.redalyc.org/articulo.oa?id=34014049006

How to cite

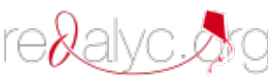

- Complete issue

- More information about this article

Journal's homepage in redalyc.org

Scientific Information System Network of Scientific Journals from Latin America, the Caribbean, Spain and Portugal Non-profit academic project, developed under the open access initiative 


\section{Democratic government, institutional autonomy and the dynamics of change*}

JOHAN P. OLSEN

\author{
ABSTRACT \\ Against the backdrop of decades of public sector reforms in Europe, \\ this essay aims to make sense of the processes through which \\ institutions, democratic government included, achieve and lose \\ autonomy or primacy and why it is difficult to find a state of \\ equilibrium between democratic government and institutional \\ autonomy. \\ The analytical value of 'autonomy' as detachment-from-politics \\ and the apolitical dynamics of change assumed by NPM reformers \\ are challenged. In contrast, the interplay between democratic \\ government and institutional autonomy is interpreted as an artifact \\ of partly de-coupled inter-institutional processes involving struggle \\ for power and status among interdependent and co-evolving insti- \\ tutions that are carriers of competing yet legitimate values, interests \\ and behavioral logics. The problem of finding a stable equilibrium \\ between democratic government, autonomous agencies and \\ non-majoritarian institutions, is illustrated by the cases of public \\ administration and the public university.
}

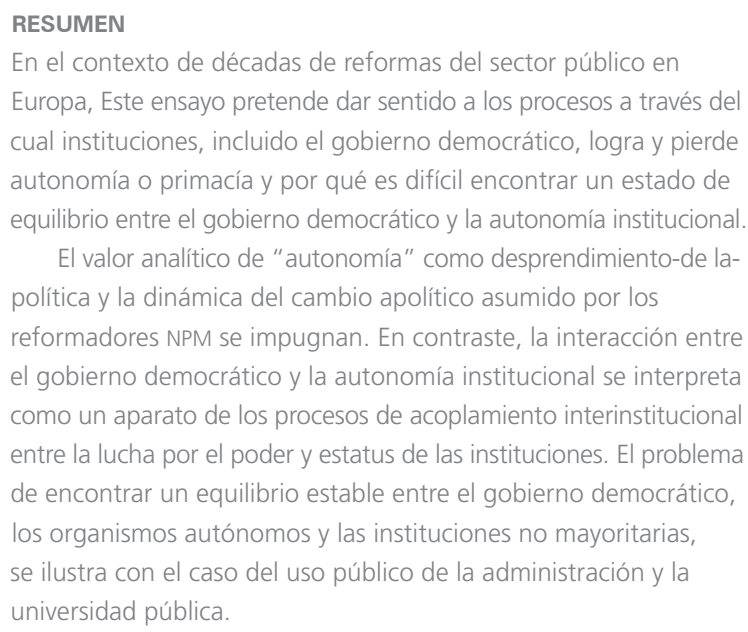

\section{AN OLD ISSUE REVISITED}

All political communities face the challenge: what form of government is normatively best and also sustainable? The agenda question is: what is the proper scope of involvement of government in different parts of society? What parts of the economy, education, civil society, religion, family life, etc. shall be politically governed or guided? What tasks, purposes and responsibilities shall belong to the public realm and what inalienable immunities, rights and freedoms shall belong to the private realm? The institutional question is: what are the proper forms of government involvement? Through which institutional mechanisms and instruments are public authority and power to be expressed and exercised? What should be the relations between majoritarian and non-majoritarian institutions? When should the majority rule through democratic collective decision-making? When should decisions be made by non-majoritarian, 'guardian' institutions insulated from democratic government and politics, and on what basis should such entities make their decisions?

The answers given to these questions have varied across polities and over time, and this essay addresses the dynamics of change over time against the backdrop of three decades of public sector reforms in Europe. The predominant 'market-and-management' trend implies to give administrative agencies more independence from majoritarian-based institutions and common sets of rules. Administrative entities have 
been placed at arm's-length from direct intervention by political authorities. There have been structural devolution (vertical specialization), more singlepurpose organizations and horizontal specialization, and separation of the state's roles as owner, administrator, regulator, purchaser, and provider. ${ }^{1}$

'Agencification' has come together with a general institutional detachment from democratic government and politics. There has been a development from 'Old Public Administration' to 'New Public Management' (Dunleavy and Hood 1994) and from direct government intervention to a regulatory state (Majone 1996, Rhodes 1996, Pierre and Peters 2000, Gilardi 2008). Non-majoritarian institutions, not directly accountable to governments, ministries, voters and elected representatives, have been given more autonomy, and it has been argued that the single most important dimension along which institutions vary is their degree of independence from the political process (Majone 1998: 25).

Reforms have primarily been justified in terms of substantive performance and good government. Key words have been efficiency, adaptation to citizens' demands, better management, modernization, competitiveness, prosperity and progress. The detachmentfrom-politics trend, however, has implications for the public sector's core normative and organizational principles and potentially challenges the territorial state as the key political actor, community and basis of solidarity. Historically the scope and organization of the public sector have been contested, and this essay aims to make sense of the processes through which institutions, democratic government included, achieve or lose autonomy or primacy and why it is difficult to find a state of equilibrium between institutional autonomy and democratic government.

First, there is the question of what 'autonomy' means and what phenomena the term refers to for reformers and how they justify claims for autonomy. Competing conceptions are discussed and the usefulness of 'autonomy' for analytical purposes is questioned. Second, an institutional framework is presented as a supplement to the explanatory frames currently most popular. Third, while autonomy reforms involve a variety of entities (administrative agencies, courts of law, central banks, regulatory agencies, audit agencies, universities, hospitals, etc.), the analytical framework is applied to two institutional settings: public administration and the public university. Finally, some hypotheses are presented regarding the shifting balance between democratic government and autonomous agencies and non-majoritarian institutions.

1. Christensen and Lægreid 2001, 2006a, 2007a, Thatcher and Stone-Sweet 2002, 2003, Pollitt 2003, Pollitt et al. 2004, Verhoest, Peters, Bouckaert and Verschuere 2004, Yesilkagit and van Thiel 2004, Verhoest, Bouckaert and Peters 2007

\section{AUTONOMY: A MULTI-FACETED CONCEPT}

The demand for autonomy has been embraced by many. There is, however, no agreement about the precise meaning and desirable scope of autonomy. Neither is there agreement about the processes through which, and the conditions under which, autonomy is gained, maintained or lost, nor which normative and organizational principles' 'autonomous' entities should be governed and which decisions should be made.

\section{Conceptualizing autonomy}

Auto nomos, referring to the Ancient Greek citystate implies self-governing and the right to organize one's internal affairs and give the law to oneself without external interference. Much later the term was linked to the European territorial state. The meaning of the term has, however, been modified by several historical developments, raising issues about autonomy for whom, from whom, in what respects, how, and why? Three key processes have been observed:

- Individualization and the claim that the moral and reflexive individual person has a standing independent of government. Individuals have rights, immunities and freedoms and they are capable of making individual, responsible decisions.

- Institutional differentiation and functional specialization and the right of institutions to function according to their own normative and organizational principles and behavioral logics, and a similar right for specific groups (estates, corporations, guilds, professions).

- Internationalization and the emergence of the European Union, making states, institutions and individuals accountable to international and European regimes and law, and raising the issues, who are legitimate participants, what is the appropriate level to exercise public authority and power and how the borders of political community should be drawn.

'Autonomy' as self-governing and not being subject to the external influence of any person, institution, state or supranational entity then applies to several units and raises questions about what the relations between competing conceptions of autonomy are, and whether different types of collective self-governance enhance or prohibit other types of collective and individual autonomy. We are interested in de-facto, and not solely legal, autonomy. Formal-legal organization often represents broad categories that allow considerable variation in practice, while de-facto autonomy involves both the absence of external interference and the capability of an agency or institution to exploit available spaces to maneuver. What, then, does 'autonomy' mean, and what does it refer to, in recent market-and-management autonomy reforms? 


\section{Selective autonomy}

The stylized argument of autonomy reforms inspired by the New Public Management (NPM) and neoliberal economic theory is that increasingly complex, dynamic and competitive societies require more organizational flexibility and professional management. Existing forms of public-sector organization and government are hierarchical, rule-bound and excessively rigid. They hamper performance, adaptability and competitiveness. Therefore, government and formal-legal rules and procedures that are binding for the public sector as a whole should have a less prominent role and detailed regulations and micro-managing should in particular be avoided. Otherwise competitive selection will make public administration outdated and increasingly irrelevant. ${ }^{2}$

The public sector is primarily about providing services, managing resources efficiently, and securing a return on public investment. Focus is on substantive results, meeting performance targets and improving scorecards. Because market competition in the public sector is less than perfect and environments are not completely deterministic, there are constraints to be handled and opportunities to be exploited. Discretion has to be delegated to professional managers and executive boards, and the mantra is 'let the managers manage' or 'make the managers manage'. Success is perceived as depending on entrepreneurship and the ability to secure learning, adaptation, flexibility and innovation.

Professional management requires control over those providing services, as well as autonomy from government, and the rhetoric of autonomy coincided with the reporting duties of an 'audit society' (Power 1994). Because all actors are self-interested, sophisticated managerial control systems, quantified performance indicators and control staffs are needed. Authority based on professional knowledge is subordinated to managerial authority based upon formal position. External quality control is emphasized and specific agencies occupied with the ranking and rating of public services achieves a central role, even if their operations involve unsolved problems (Dickson, Hood and Jones 2008).

\footnotetext{
2. While I use a stylized model of the dominant reform trend, most reforms involve a mix of ideas and not all of them are market-and-management inspired. I have taken part in three Norwegian governmental commissions on autonomy reform. In one, A Better Organized State (NOU 1989: 5), there were tensions between advocates of hierarchical organization, bargaining arrangements, and market competition. The second, on the administration of courts of law (The Courts of Law in Society, NOU 1999: 13), focused on formal-legal autonomy from the Ministry of Justice. It was initiated by judges, chaired by the President of the Supreme Court, and had modest elements of NPM thinking. The same is true for the third, (Academic Freedom. Individual Rights and Institutional Management Needs, NOU 2006: 19). Its mandate emphasized formal-legal aspects of autonomy, but a conclusion was that limited resources, more than legal rules, represented a threat to academic autonomy and freedom.
}

NPM reforms promote a generic model across the public sector, based upon a vision of the primacy of the private commercial enterprise in competitive markets, populated by rational individual managers and consumers, mastering the world through calculation, and governed by economic incentives more than by law or norms. Other institutions have auxiliary functions: to serve the economy and help markets function better (OECD 1991, World Bank 2002).

Reforms prescribe that public administration must adapt to 'society's needs', understood as market forces, customers' and stakeholders' preferences. It is claimed that there is a tension between general rules and the flexibility requirements of economic, technological and social modernization, and primacy is given to innovation and change. Reformers give less attention to the value of continuity and the need to buffer over-adaptation to short-term fluctuations and 'the follies of the day' (March and Olsen 1989, Olsen 2008b).

Prescriptions, however, have internal tensions. The logic of independent regulatory agencies requires insulation from rent-seeking, special interest groups and corporatist arrangements that may capture agencies and create costs and inefficiencies, and also from short-term swings in public opinion and alleged myopic elected representatives who focus on the next election. While public sector-wide rules are criticized as dysfunctional, the regulatory logic portrays sector and institution-specific rules as instruments for correcting market failures. Stable and predictable public rules make private flexibility possible. 'Rules rather than discretion' are seen to create credible commitments, consistency and efficiency and the necessary distance from political and market actors (Kydland and Prescott 1977, Majone 2001). For example, independent central banks, as the guardians of a non-inflationary monetary policy are assumed to produce more efficient macroeconomic outcomes, and regulatory agencies are supposed to implement, monitor and enforce rules on the basis of professional (economic, managerial) knowledge.

Autonomy reforms then have propagated a selective, and not always consistent, conception of 'autonomy' over the last few decades. Reforms have reflected the triumph of market-management ideology and a shift towards doctrines of economic laissez-faire, government non-interference, and 'governance without government' (Rhodes 1996, Pierre and Peters 2000). In an era when the Zeitgeist has been anti-political and prescribed the selfregulating market as society's key institution, mainstream reforms have celebrated individualism and internationalism, 'good government' as policy performance, individual choice and voluntary exchange, competition, and entrepreneurs and consumers governed by supply and demand, prices, 
incentives, private contracts, and economic knowledge, within a framework of a regulatory state, constitutionalism and separation of powers. Reformers have largely ignored variations in institutional identities, behavioral logics and procedural rationalities. They have been skeptical to a strong, intervening state, general rules and 'good government' defined as procedural rationality, 'bureaucracy', (some types of) professional self-governance, and corporatist arrangements -a reform package more alien to Scandinavia and Continental Europe than to the United States.

Arguably, reformers conceptualize 'autonomy' as a management tool for achieving efficiency. They use the term for a transfer from one set of external dependencies (political, legal, bureaucratic) to another (markets, managers, 'stakeholders', external rating and ranking entities), rather than insulation from all external influence. This conception hides more than it reveals. The multidimensional and contested character of 'autonomy' and 'accountability' (Roness et al. 2008, Schillemans 2008), the many combinations observed, and the fact that different dimensions of autonomy are not necessarily positively correlated (Christensen 2001, Verhoest, Peters, Bouckaert and Verschuere 2004) make it problematic to draw conclusions about change in autonomy beyond a single relationship (parent ministry and agency), subject matter (organization, budget, personnel, policy), or instrument (legal rules, economic incentives). Because there is no common metric for summarizing across all relevant dimensions, the term may be less fruitful as an analytical tool for understanding public sector dynamics than as a vehicle for political purposes. 'Autonomy' is potentially a useful term because it carries positive overtones and at the same time is ambiguous and leaves room for alternative interpretations.

Therefore, rather than seeing reforms solely as functional improvement, modernization and good government, it may be worthwhile to explicitly consider the tensions involved and explore how the politics of legitimate forms drive institutional change (Powell and DiMaggio 1991). The next part suggests that reforms can be understood as part of a continuous struggle for a place in the larger institutional order. Reforms involve attempts to legitimize and delegitimize and shape and re-shape institutions, change their status and power, and affect what kind of political and social order will develop.

\section{FRAMES OF INTERPRETATION}

Attempts to make sense of autonomy reforms have been dominated by two frames, both using an instrumental language of functional improvement to describe, explain and justify reform. Organizational forms have been assessed according to their expected substantive results and how 'practical' and 'suitable' they are expected to be.
Change is society-driven or government-driven. The first assumes priority for societal dynamics and argues that autonomy reforms are dictated by the functional requirements of social transformations and an increasingly complex and dynamic society. Change reflects the empirical characteristics of a changing world and autonomy is a necessary consequence of economic and technological globalization, long-distance migration, demographic and cultural change. Democratic politics is not a 'master sphere' in the Aristotelian meaning of having authority and capability to establish institutions, protect their identity and proper role, and draw institutional boundaries.

The second -embedded in the Enlightenment's belief in the key role of human will, understanding and control in political and societal developmentsmaintains that reforms result from deliberate political delegation. The primacy of democratic politics is assumed. Government is the architect of political order, designing, reforming and eliminating institutions, and the democratic logic assumes priority for political contestation, the electoral system and political representatives. Autonomy involves a distinct mode of ruling. Institutions and actors are given autonomy in order to promote the common interest, as interpreted by government and legislature. Agencies are not fully independent. Their status is defined in public law. The ministry can alter their budgets and main goals, and delegated autonomy can be recalled, for agencies as well as non-majoritarian institutions.

In practice, the two frames are often combined, as government policy is presented as responses to societal change. The paper, however, adds a third frame, giving priority to the organizing role of institutions. An institutional approach, as understood here, sees institutions as having a partly autonomous role and independent explanatory power. Institutions are not epiphenomena that mirror predetermined individual preferences and initial resources or societal imperatives. They are not simply equilibrium contracts among self-seeking, calculating individual actors or arenas for contending social forces and circumstances (March and Olsen 1989, 2006b). ${ }^{3}$ Their organization makes a difference and each organizational form mobilizes a bias. Each facilitates and denies access to different actors, issues, arguments, conflicts, and resources (Schattschneider 1960, Cohen, March and Olsen 1972, Egeberg 2006a). However, individual institutions are placed in a larger, more or less legitimate political and social order, and their performance and legitimacy are affected by their interdependencies and relations to other institutions. Change in the institutional order

3. This perspective differs from Lijphart's (1977) more society-centered analysis of consociational democracies, where institutional autonomy is rooted in segmental cleavages and verzuiling of society. 
affects the likelihood that issues and conflicts will be dealt with inside or outside the political system, the relative importance of different institutions and interests, and substantive outcomes.

One implication is that we have to take into account complex inter-institutional relations and not a single principle-agency relation. Another implication is that the normative attractiveness and viability of a political order are not necessarily based upon concerns about economy and efficiency. A democratic order cannot rely on a single-indicator measure of success. A legitimate order has to achieve citizens' support and accommodate a variety of success criteria. Reforms raise questions such as, how should authority and power be allocated, exercised and controlled and according to what normative standards is legitimate power to be defined? Involved are the power of the state, the power over the state, and the opportunities and constraints within which institutions and groups are expected to operate.

Most importantly, democratic government has to prevent destructive conflicts, societal chaos and breakdowns, and an enduring theme in political philosophy is how (a) legitimate government and (b) limited government and avoidance of power concentration are interrelated and legitimacy depends on balancing political and societal power. Beginning with the separation of state and church, which contributed to both secular government and church freedoms, successful conflict regulation has been linked to century-long processes through which new institutions have split off from older ones and developed different identities and degrees of autonomy, validated by society at large: democratic politics, public administration, law, the judiciary, civil society, market economy, religion, science, art, and the family. Institutions have co-evolved as part of the historical development of democratic government and societies. There has been privatization or depoliticization of some institutional spheres, representation and participation of organized societal interests in public policy-making and administration, and development of impartial, 'guardian' institutions.

Therefore, it is of some value to get history right and not start out with an assumed sovereign, monolithic state with centralized command and control and delegation and accountability as dominant processes. Exempting agencies and institutions from central, ministerial control is a well-established phenomenon in many countries (Olsen 1983, Carpenter 2001, Christensen 2001, Wockelberg 2003). Sweden, for example, has a centuries' long tradition of formal autonomy (Larsson 1994, Wockelberg 2003) and the phenomenon is also well known in countries that are often portrayed as 'agency laggards', such as Germany (Döhler 2002, Bach and Jann 2008).

There has been change over time. There have been periods of legitimate institutional order based upon shared understandings of, and trust in, normative and organizational principles, institutional purposes, inter-institutional relations, and appropriate use of discretion and resources. Formal arrangements and informal understandings have, however, been incrementally adjusted in the light of experience and there have been periods of reorientation and institutional breakdown. Existing orders have been challenged and upset, with attempts of emancipation, encroachment, and defense of institutional identity and position in the institutional order (Olsen 2008b). Institutionalization, de-institutionalization, and re-institutionalization have taken place as the legitimacy of old institutional identities and borders have been challenged and new institutions and relationships have been established, generating new forms of integration and separation, new power and status relationships and forms of dominance and accountability. ${ }^{4}$ For example, in some contexts and historical periods democratic politics and government have been seen to have a legitimate ordering function, determining the relations between society's basic institutions. In other contexts and periods there have been reduced trust in, and flight from, democratic politics and government, and the importance of other institutions and actors has been emphasized.

An institutional approach then supplements a conception of institutional change as technicalfunctional improvement by a conceptualization of reform as part of a continuous inter-institutional struggle for legitimacy and support. Autonomy results not from a single process of environmental necessity or strategic choice. Change is an artifact of several (often) loosely coupled path-dependent processes and the flowing together of, for example, a desire to relieve political leaders and ministries of time-consuming and boring tasks or political blame, legal doctrines of court autonomy and individual rights, neo-liberal economic doctrines, NPM ideology, and financial managers and central banks, scientists and universities, as well as religious movements and churches, struggling for a more central place in the institutional order.

Institutionalism shares with the governmentdriven approach the idea that demands for more (or less) autonomy are related to discontent.

\footnotetext{
4. Institutionalization is both a process and a property of organizational arrangements. Institutionalization as a process implies that an organizational identity is developed and legitimacy in a culture is built. There is increasing clarity, agreement and formalization of: (a) behavioral rules, including allocation of formal authority; (b) how rules are to be described, explained and justified; and (c) what legitimate resources are in different settings and who should control common resources. De-institutionalization implies that existing rules and practices, descriptions, explanations and justifications, and resources and powers are becoming contested and possibly discontinued. There is increasing uncertainty, disorientation, and conflict. New actors are mobilized. Outcomes are more uncertain, and it is necessary to use more incentives or coercion to make people follow prescribed rules. Re-institutionalization implies either retrogression or a transformation from one order into another, constituted on different normative and organizational principles (Olsen 2008b).
} 
Performance and legitimacy crises make possible interventions and changes otherwise not acceptable. In eras of transition, shared vocabularies, accounts, and normative standards are called into question. Frames of mind change as actors test out ideas about whom they and others are and can become; how common affairs are and can be organized and governed; how specific institutions are to be run and by whom; and how institutions can be made to fit together in a democratic order. It then becomes evident that the meaning of concepts such as 'autonomy' and 'good government' is not an inherent property; it changes over time as part of the processes of interaction and reconceptualization (March and Olsen 1976, 1995, March 1981, Ball, Farr and Hanson 1989)..$^{5}$

How, then, do citizens and officials develop and lose confidence in institutions or political systems? For example, why is there change in the ideological climate so that market liberalization, managerialism, a regulatory state, and institutions insulated from politics are celebrated (Verhoest, Peters, Bouckaert and Verschuere 2004)? How do decision-makers come to believe that European interests are best protected by non-majoritarian institutions such as the European Commission, the European Court of Justice, the European Central Bank, or autonomous agencies? How are such trends reversed?

An institutional approach assumes that both crises and routine events are interpreted through institutional lenses. People identify with, and have trust in, different institutions and coordination mechanism, such as hierarchy, markets and price systems, voting arrangements, corporatist bargaining, rule-systems, and expertise-based entities. Identification and trust in turn influence interpretations. For example, interpreting the 2008 financial crisis, market skeptics were more likely to blame socially irresponsible financial leaders and bankers, largely unregulated private equity and hedge funds, and credit-rating agencies. Market enthusiasts were more likely to blame politicians and wrongheaded government policies, incompetent regulators, and 'bureaucrats' .

\footnotetext{
5. Manipulation of the meaning of "bank", which allowed financial institutions to circumvent existing regulations because they were not "banks", contributed to the financial crisis.

6. The two anonymous reviewers suggested that confidence in self-regulating markets will come under sustained attacks due to the financial crisis. One of them also asked whether the analytical perspective of the paper allows predictions about institutional reactions (and outcomes). An institutional approach views performance crises as favoring change. Nevertheless, this approach also has to take into account that the market-ideology is embedded in strong institutions and supported by powerful actors. Many public and private actors admit that the current crisis represents a major system failure. Yet they also reconfirm that they still believe that market systems in the long-run will provide the best results. My expectation is that the market-ideology will loose some of its hegemony. Nevertheless, if the crisis does not increase or last for an extended time, there is likely to be incremental institutional modifications rather than institutional revolutions.
}

Some institutional mechanisms are well known. There is sequential attention to problems and success criteria (Cyert and March 1963). Reforms are often 'oversold'. Reformers promise too much or generate countervailing forces because they purify a single principle, be it autonomy-control, decentralizationcentralization, or specialization-coordination (Kaufman 1956, Jacobsen 1964, Verhoest, Bouckaert and Peters 2007). Change may follow from increased interaction and exposure to new experiences, for example through cooperation in the EU (Olsen 2007a, 2008b) and it makes a difference what resources are mobilized behind different prescriptions and interpretations. For example, many international financial institutions have imposed, or made a condition for partnership, a neo-liberal conception of 'good government' based upon the primacy of markets and NPM managerial principles and the Maastricht Treaty made independent central banks a precondition for entry into the single currency (Thatcher and Stone Sweet 2002: 13).

Change in autonomy also depends on how formal authority and power are used in practice. Self-restrain has been part of a civilizing process changing institutions and human actors (Elias 1994), and restraint affects variations in suspicion or trust in institutions. Good government implies exercising authority and power in accordance with fairly stable principles, approved procedures and recognized authority, for example impartiality (Rothstein and Teorell 2008). Leaders as well as non-leaders are supposed to be governed by rules of appropriate behavior in specific roles, and situations and procedural rationality are based on the intrinsic merit of specific procedures. There is no proven right or superior result beyond what is generated through a specific process (e.g. democratic election, market competition, force-free deliberation, bureaucratic rule-following or lottery). Yet what is appropriate in one institutional sphere is inappropriate in others and inter-institutional tension is a source of political change (March and Olsen 1989, 2006a,b, Olsen 2007a).

It is beyond this essay to systematically analyze variations across polities and institutional spheres. The next two parts limit themselves to an illustration of the approach sketched above by addressing two favorite targets of reform: first, models of public administration and hence 'the bureaucracy' and, second, Humboldt's vision of the University -two old European institutions with Prussian roots. While autonomy reform is not a new phenomenon, the three last decades represent a potentially transformative period with major efforts to change autonomy -patterns- efforts with different starting points, reform elements, trajectories and outcomes. We attend to the diagnoses and recipes of reformers, characteristics of the institutions intervened in, and results achieved. 


\section{MODELS OF PUBLIC ADMINISTRATION}

Prügelknabe number one for NPM reforms is the bureaucracy' and the criticism has both an agenda aspect and an institutional aspect. For many reformers 'bureaucracy' means an overly large and intervening public sector, a centralized top-down command and control-model characterized by hierarchy and rules, or simply everything that is wrong with the public sector. Main stream autonomy reforms give priority to privatization and detachment from politics, managerial discretion over rule-bound behavior and results over procedures. They open up the public sector to competitive markets and partnerships with societal actors. ${ }^{7}$

Reforms, therefore, challenge a well-established understanding of what the public sector is for and how it should be organized and governed as part of a democratic order. A politically accountable, ruledriven, professionally competent and neutral public administration has for some time been a cornerstone of the European state and a dominant model has been Weberian bureaucracy, emphasizing the value of efficiency, coherence, consistency, continuity and predictability. Compared to the 1960s, celebrating the intervening welfare state as the planner of society and 'mixed economy' as an alternative to market economy (for example in Scandinavia) reforms also challenge the role of the state as the dominant actor and structure and provide a new test of the power of the political center. The outcome of such reforms, however, depends on how well reformers understand and control the 'bureaucracy's' organization and operation.

\section{Weberian bureaucracy}

A Weberian bureaucracy signifies an institution with a raison d'être of its own, based upon a clear distinction between the public and private sectors (Weber 1978). Bureaucracy is a composite organizational form founded on three legitimate, yet competing principles:

- Hierarchical authority based on formal position, the electoral mandate given by citizens at the ballot box, and expressed through representative government.

- Rule-based authority embedded in constitutions, Rechtsstaat principles, and laws authored by the legislature and interpreted by the courts.

- Expert authority based on specialization and professional, impartial and non-partisan knowledge, and principles of enlightened government.

\footnotetext{
7. The selective, shifting and conditional character of administrative and institutional autonomy is illustrated by the contrast between the current mantra "let the managers manage" and the criticism of public administration 30 years ago. Then the need to restore the rule of law and legal enforcement capacity was emphasized, against the tendency to delegate powers to administrative agencies without clearly defined legal standards of implementation (Lowi 1979).
}

Bureaucrats are expected to be loyal to elected leaders, but not a tool for executing arbitrary commands. In applying the law to individual cases, public administration is to be 'autonomous' -legally insulated from day-to-day interference by elected leaders, political parties, organized interests, and individual citizens. Bureaucrats are supposed to be the servants and guardians of legal and professional rules, to illuminate all aspects of public policies, and be insensitive to immediate political and economic expediency. The bureaucracy, nevertheless, is embedded in a larger order and system of expectations. The legislature/executive, the courts, and the University are gatekeepers who regulate relations between public administration and the public (Olsen 2008a).

\section{Democratic order}

What is usually called 'democracy' is a form of ordered rule involving an institutional sphere with the task of governing a territory and population. Political institutions have some autonomy from other spheres of society, absorptive and adaptive capabilities, and internal differentiation and coordination of offices and roles with specified authority and responsibility (Huntington 1968). Democracy is based on the logic of equality and a decisive role of the common people. It is a system of rights, as well as an instrument for attaining preestablished goals and a framework for developing and transmitting democratic beliefs (Dahl 1998).

However, democracies have not inherited a coherent set of principles and institutions that define good government and administration. They have inherited elements from different traditions. Over time democratic compromises and struggles have been encoded into configurations of interdependent, but partly autonomous, institutions based on competing normative and organizational principles and with separate origins, histories and dynamics, and balancing autonomy and democratic control is related to the question: In a world of competing rationalities, conceptions of truth and rivaling justices, which rationality and whose justice will prevail (MacIntyre 1988)?

In this perspective authority and power founded on competitive elections and numbers are not a totally dominant democratic value. It is balanced against institutionalized individual and minority rights that prescribe limits of public intervention and citizens' obedience. Neither can it be assumed that a single center is capable of reforming the public sector at will so that autonomy is solely a question of political delegation and accountability. Representative governments are neither omnipotent nor impotent and the significance of numerical strength in administrative history has shifted. Relationships have gone through ebbs and flows and variations in political power and administrative autonomy have 
been related to political saliency and the level of conflict in society (Jacobsen 1964, Christensen 2003). It has been difficult to legitimately delegate decisions to agencies and non-majoritarian institutions when issues are contested and mandates, goals, rules and procedures are not specified in some detail (Majone 1998).

While a society-driven perspective underestimates political power, a government-driven perspective overestimates the power of reformers. Both underestimate the autonomy of law and that a weakening of formal-legal affiliations to central authorities stands in contrast to legal control and judicial review, with courts of law defending individuals against abuse of discretionary administrative power. The principles of the rule of law (and not managers) and due process have historically been an emancipatory force that constrains arbitrary discretion. The instrumental view of law as externally imposed discipline, dominant in autonomy reforms, has also been supplemented with the idea of law as justice -rules with a defensible normative content, defining appropriate behavior, generating pressure for compliance, and possibly changing identities and collective understandings (Berman 1983, Habermas, 1998). Still, the possibility that law may be corrupted by economic, class, religious and political interests and by the judiciary has also been observed (Habermas 1996: 172). Actually, since the ancient Greeks it has been debated in what respects law, as a method for governing human cooperation and conflict resolution, has developed into an autonomous sphere with a distinctive identity, internal order and history, and to what extent law is integrated into other institutional spheres (Foxhall and Lewis 1996).

The issue is relevant because autonomy reforms have come together with an international rule explosion (Ahrne and Brunsson 2004), a rights revolution (Sunstein 1990), and a global expansion of judicial power (Tate and Vallinder 1995), and because the interaction between economic, legal and political institutions is crucial to understanding European transformations. While market freedoms have gained an overriding constitutional-like status in the European Union, the EU is constituted and integrated through partly autonomous legal processes. Understanding the law as an epiphenomenon of political will, economic and social forces, or in terms of judicial autonomy (law as governed exclusively by legal doctrines and techniques of interpretation), is perceived as naive and uncompromising understandings. The dynamics of law is analyzed as part of larger inter-institutional processes (Joerges 1996, Armstrong 1998, Sand 2008), a perspective that also sheds light on reform outcomes.

\section{Uncertain outcomes}

Public administration has been encroached on by an alien institutional logic and account of how it works and should work, and there could be a long-term transition to a new order, as institutions and levels of governance are reconceptualized, gain and lose legitimacy, and become more closed or open to external influences. European institutions may be entering a stage with new internal and external divisions of authority, power and accountabilities. The political executive in Europe is changing (Egeberg 2006a, Curtin and Egeberg 2008) and a new multi-level and multi-centered polity is emerging in the interplay between the internal dynamics of each institution and international, European, national, and local processes (Olsen 2007a). An institutional approach, however, predicts that well-entrenched bureaucracies are not easy prey for societal forces or deliberate reforms.

Reforms include elements of centralization, contracts and monitoring as well as decentralization, managerialism and autonomy and it is an empirical question whether administrative entities have achieved more de-facto autonomy, and with what effects, or whether there is more market, societal and political control. While agencification tends to make signals from the political center less important (Egeberg 2003, Egeberg and Trondal 2008), there has not necessarily been a general loss of democratic power, and elected leaders may even have tightened the grip on public administration. Reform trajectories and outcomes have varied across countries, institutional spheres and have been affected by traditions and practices in specific countries (Christensen and Lægreid 2006b, 2007a, b, 2008).

Reforms have contributed to increased attention to the results achieved by the public sector. Functional superiority and efficiency gains are, however, difficult to prove (Verhoest, Peters, Bouckaert and Verschuere 2004, Christensen, Lægreid and Stigen 2006). The conditions under which institutional arrangements work as intended are not well specified and there is weak evidence regarding the claims of improved ability to learn, adapt and compete. While 'autonomy' is often interpreted in legal terms, formal-legal affiliation is an uncertain predictor of how autonomy is used in practice and it is necessary to go beyond the formal powers of government and agencies in order to understand how their relations work in practice (Larsson 1994, Pollitt 2003, Christensen and Lægreid 2007b, Yesilkagit and Thiel 2008). For example, practice deviates from the regulatory rhetoric's prescription of autonomy from political and market actors (OECD 1997, 2002a, b). Signals from different sources are taken into account, including the parent ministry and those regulated (Christensen and Lægreid 2007b, 2008).

In Norway there is long tradition for using the central authorities' right and obligation of instruction and organization with reason in order to find the 'right' balance between democratic control and institutional independence (Forvaltningskomiteen 
1958, NOU 1999: 13, Christensen 2003). In many institutional settings it has nevertheless been difficult to find a stable equilibrium (Egeberg 2006b, Lægreid, Verhoest and Jann 2008). For example, a study of Norwegian hospital reform shows that balancing political control and health enterprise autonomy is precarious. Reform goals were to enhance coordination and efficient resource utilization, and hospitals changed from being public administration entities to health enterprises. Formal decentralization gave subordinate bodies more discretion, but also new performance management and reporting systems. Elected politicians were replaced by professional experts on executive boards. Still, many aspects were not regulated by the formal framework and the balancing of autonomy and control was subject to continuous interpretation and adjustment. There were collisions between NPM reform ideology and a Norwegian tradition of governmental intervention and control. Within a zone of indifference managers could operate freely. Politicians, however, did not abdicate and they were particularly activated in sensitive issues, with popular protest against redistributive policies. In practice, rather than replacing existing arrangements, NPM principles were added. An effort was made to integrate performance management into an existing trustbased culture. Yet, as national, regional and local politicians were mobilized as a lobby against health enterprises, the state became a less cohesive and consistent owner and actor (Lægreid, Opedal and Stigen 2005, Christensen, Lægreid and Stigen 2006).

More generally, reforms have generated countervailing forces and a renewed tension between agency discretion, initiative, and flexibility and political accountability and control. OECD and others call attention to how one may ensure political coordination, policy consistency, a coherent public service, guarantee accountability, and protect the public interest when highly political questions are left to autonomous experts in autonomous agencies (OECD 2002b). A new generation of post-NPM studies is concerned with central political capacity and coordination and how public administration can be made more responsive to elected leaders

(Christensen and Lægreid 2006a, 2007a), as well as how giving priority to economy and efficiency may undermine traditional public service values and bureaucratic virtues such as due process, fairness, impartiality, honesty, equity, predictability, continuity, and democratic control (Pollitt 2003).

\section{Speculations}

Historically, under what conditions administrative processes can be insulated from external influences remains an open question (Bendix 1977: 155). In addition recent reforms remind us that 'state' is a historically delimited term that has been reinterpreted as part of major transformations throughout time
(Bendix 1968: 9), as have other terms such as 'bureaucracy', 'law', 'democracy', 'good government' and 'market'. The claim that current reform patterns are complex, changing, and not easily understood (Roness et al. 2008) resembles the older observation that it is not easy to find the reasons behind each case of administrative reform (Forvaltningskomiteen 1958: 25, 35)

At the rhetorical level 'bureaucracy' has few defenders. However, 'bureaucracy' is frequently used as a political slogan more than an analytical concept, and change at the behavioral and organizational level is not always positively correlated with change in rhetoric, intentions, visions and myths. It is possible that a highly criticized organizational form survives because it protects central values and procedures and because its composite nature generates flexibility between hierarchical orders, rule-application and professional judgment rather than excessive rigidity (Olsen 2008a). Interpretations of and attitudes towards autonomy reforms are also affected by political-administrative traditions. In a legalistic culture, such as Germany, legality and law-enforcement are perceived as more important than economic efficiency. Change is driven by policy substance and political leaders tend to define administrative autonomy as a practical solution to practical problems and not a question of power. They are not (like NPM reformers) obsessed with the problem of misuse of administrative power. Ministerial influence is also seen as a legitimate expression of the political supremacy over administrative affairs and not as subverting administrative expertise and neutrality (Döhler 2002, Bach and Jann 2008).

Why, then, do reforms steadily create demands for new reforms? A speculation is that it is difficult to find a stable equilibrium between institutional autonomy and democratic government, not only because reforms are contested, but also because the structural and dynamic features of the existing institutional configuration are not well understood by reformers who assume societal determinism or deliberate political design. Reformers misinterpret the administrative/ political/legal order they intervene in and defy a European heritage that has not only experienced the state as a threat to institutional and individual autonomy, but also as the guardian of autonomy.

These speculations are elaborated by attending to European-level university reforms. The principle of enlightened government and theories of bureaucracy and democracy give impartial expertise, merit-based authority and academic freedom an important role. Nevertheless, another Prügelknabe of autonomy reforms is the Humboldt vision of the University.

\section{MODELS OF THE PUBLIC RESEARCH UNIVERSITY}

University reforms, portrayed as 'modernization' have taken place in most European countries and higher 
education in Europe 'have been undergoing a major transformation' (Eurydice 2008: 11). While there are detectable developmental trends, no single predominant European model for university governance has emerged (Paradeise et al. 2009). In its diagnosis of and recipe for university reform the EU Commission, however, comes close to the stylized NPM reform model. A standard vocabulary, organizational scripts and models of management inspired by private business and neo-liberal economics are imported in order to reform one of Europe's oldest institutions.

\section{Anti-Humboldt}

The diagnosis is well known. The Commission argues that European universities do not deliver. They are outperformed in global competition, partly due to the 'Humboldt-model' and ivory-tower thinking. They operate in a fast-changing environment but are isolated from society, overregulated and underfinanced. Universities are inherently conservative institutions, defending their privileges, while being unresponsive to economic and social needs. Now they are to be measured in terms of productivity and competitive performance. They must generate income and contribute more to Europe's economic competitiveness and development. Higher education and research are private consumer goods more than a public good. Faculty members are service providers and students are consumers (Maassen and Olsen 2007).

An important part of the recipe, summarized in the Lisbon Declaration (April 2007), is that for universities, the adaptability and flexibility required to respond to a changing society relies above all on increased autonomy and adequate funding'. In several documents it is repeated that universities will not become innovative and responsive to change unless they are emancipated from over-regulation. In return universities should accept full accountability to society at large for their results. The emerging 'knowledge economy' requires university autonomy, competition and diversity, external quality assurance, accountability, and sustainable partnerships with the broader community, industry, and other stakeholders. Greater autonomy and complexity, in turn, require flexibility in organization, professional management, improved internal management systems and cost control. Public authorities should not be less responsible for universities, but their relations to universities should change (Commission 2005, 2006, Maassen and Olsen 2007).

Claims for autonomy are not based on a vision of the University as an academic and cultural institution with a long history and identity of its own. When the Commission argues that change should take into account the university's peculiarities, the language is vague and overwhelmed by the dominant marketmanagement perspective and criticism of the Humboldt legacy.

\section{An appropriate concept or ambition?}

There are competing diagnoses and recipes defending the Humboldt vision. The University is a unique selfgoverning institution with a core academic mission and mandate, not a profit-seeking enterprise, and it must be morally and intellectually independent of both political authority and economic power (e.g. Magna Charta Universitatum 1988, Council of Europe 2006). The University's identity and ethos is based on free inquiry and truth-finding for its own sake. Autonomous, disinterested, critical and enlightened scholars in pursuit of knowledge are following the logics of reason and empirical evidence, decoupled from immediate political and economic utility, religious and moral concerns, received wisdom and traditions.

Organizationally the community of scholars is characterized by a loose linkage between the constituting units of the University and a relatively weak center, collegiate leadership, elected leaders, organization by discipline, and research-based instruction. Activities take place within the wider context of an international community of scholars based on competitive merit and peer review and self-discipline. Universities are seen as playing a vital role in the development of the European humanist tradition and civilizing processes, and the intrinsic value of academic freedom and autonomy is part of a cultural commitment. The state shall not intervene and it shall prevent others from interfering in academic affairs. Universities have mostly proved capable of simultaneously answering external and internal demands in the pursuit of free and universal knowledge. Within this perspective, the Council of Europe talks about readjustment rather than radical reform.

It is difficult to imagine total university autonomy from external influence as the norm or practice. Historically, the University has been exposed to many as well as contradictory expectations. There have been cycles of separation and integration as the boundaries between the University and political, administrative, military, economic, religious, ethnic and social institutions and groups have been opened or closed. During the Bergen 2005 meeting of the Bologna process, it was also asked whether 'autonomy' is an appropriate concept or ambition considering the central role higher education institutions have in present-day societies where mass education is a public responsibility that rests with governments and large investments are involved. Universities have to be accountable to society and autonomy has to be a question of degrees and conditions (Ullenius 2005).

The problem is where and how the limits of institutional autonomy and individual freedom are to be drawn and the Council of Europe warns the University against isolation and not reacting to society's changing needs. Academic freedom and 
autonomy should remain a subject of continued and open dialogues between the academic world and society at large, and with the advent of the knowledge society, a new contract has to be reached between the university and society. ${ }^{8}$ University reforms, furthermore, illustrate that it is important to distinguish between legitimate and illegitimate, desired and undesired external interventions. Universities want self-governance, but in order to work well, they also need external support and good relations with other institutions. Many academics, for example in Norway, mobilized against reforms prescribing a looser formal -legal affiliation to the state- a reform interpreted as reduced state commitment to universities.

\section{More autonomy or less?}

Are universities then gaining or losing de-facto autonomy? The European Commission, referring to the University's formal-legal affiliation to government, claims that universities have become increasingly autonomous in many European countries over the last few years (Commission 2005). Others ask whether the European research university is just a historical parenthesis (Neave, Blückert and Nybom 2006) or argue that there is institutional autonomy with increasing dependency on outside actors'. While there is more legal autonomy, other external pressures impinge on the University's autonomy rather than those of the state, including external funding, accreditation and quality control (Bladh 2007, also NOU 2006: 19).

As its perceived societal relevance has increased and higher education has expanded and become more costly, the University has become accountable to more external actors. There are shifting calls for relevance, which parts of society the University shall serve and in what ways. There are competing ideas about how universities should be organized and governed, who shall run them, and who will be the future guardians of the University as an academic institution. There are also struggles over what it takes to deserve the name 'university' and what the term should signify in the future. Arguably, as reforms have challenged the University's institutional identity, the international scientific community as a selfregulating system, and research and higher education as a specific policy sector, the University has become a less distinct institution, partly characterized by institutional confusion and the search for a legitimate place within the social order (Maassen and Olsen

8. The Council of Europe has been an important arena for debate and several publications on university autonomy have been edited by Sjur Bergan, Head of the Council's Higher Education and Research Division.
2007). In brief, the contemporary external environment invites a complex mix of independence and control, not easily captured by the term 'autonomy'.

The University has also become more 'managerial' (Amaral, Meek and Larsen 2003). While autonomy in some respects has increased at the university level, there has been a shift of power from academic personnel to elected leaders and the administrative apparatus. The University has evolved from a loosely knit community of scholars to a formal organization attempting to formulate common goals with increasingly higher aspirations for planning and co-ordination, more differentiated and formalized organizational structures, and an increase in administrative staff (March and Olsen 1976, Maassen and Olsen 2007). A key question for universities is whether generic, business-inspired, or universityspecific models of organization, leadership and governance will prevail.

\section{Speculations}

Does this make the University more liable to identitychanging interventions? Universities, like other institutions, appear in exemplary and perverted versions. Universities are more or less governed by the constitutive principles of the ideal academic institution and autonomy may be a necessary but insufficient condition for excellence. The relationships between the individual scholar, a specific university, and the international scientific community vary. The latter can play a more or less central role in disciplining scholars and universities. Autonomy for a university can be a precondition for, but also a threat to, individual academic freedom. The central leadership of universities and individual managers can achieve a stronger position while the individual researcher and teacher are afforded less autonomy. External intervention can follow because a university does not live up to academic standards, but protects its self-interest and privileges. Or intervention can be based on competing criteria of success, for example contributions to economic development.

The outcome of contemporary reforms is difficult to predict. The university is a composite organization embracing, for example, ideas about a community of the learned, an internal democracy, an agency for implementing public policies, and an enterprise in competitive markets (Olsen 2007b). Reforms unfold in the interaction between the internal dynamics of the University and science, international economic and technological developments, European, national, regional, and local levels of government, and in the disguise of economic, industrial, innovation, and regional policies, as well as higher education, research, and university policies.

A hypothesis is that the more loosely coupled a university is horizontally (functionally between 
schools, disciplines, departments, individual professors), the easier to change one part without serious consequences for the rest, and the more likely that specific units will be exposed to demands for change. Reforms that increase the specialization and decentralization of authority within individual universities will reduce the degree of integration and generate centrifugal forces that differentiate between disciplines and sub-disciplines with demands for their teaching and research and strong support in society and less fortunate sub-units, making the latter more vulnerable to change.

The outcome will not depend solely on formal organization, but also on whether there are shared norms of Universitas as a community of the learned that might hold a (formally) loosely coupled university together and make it difficult to eliminate or reorganize specific sub-units. Therefore, rhetoric that de-emphasizes Universitas as a 'whole', arguing that a 'university' does not need to encompass the entire spectrum of disciplines, facilitates reforms which aim to eliminate or change individual units. The more the common academic culture is weakened, the easier to implement change.

Vertical integration, stronger hierarchical authority and administrative staffs provide increasing capacity for reform. Budget cuts and exposure to competition for short-term and specified funds have changed universities, and the more costly and resource-dependent the research is, the more exposed it is to external influence. The more earmarked the budgets are, the less autonomy, but also the less internal conflict there will be. The more lump-sum budgets there are, the more autonomy, but also the more likely that there will be internal distributional conflicts and power struggles over reforms.

While the EU and it forerunners have been involved in university reforms to some degree (Corbett 2005), it should be kept in mind that ongoing European-level reforms are prescriptions more than accomplishments, that EU-level institutions are (still) more important as sources of reform ideas than as policy-makers, and that there is a discrepancy between rhetoric and practice. 'Humboldt' (like 'bureaucracy' and 'NPM') is a stylized vision with strong symbolic meaning (Nybom 2007) that historically and currently captures only part of a reality characterized by huge variations and dynamics. Contemporary reform rhetoric and its opponents talk at the level of principles for or against academic autonomy, markets and pricing systems, politicaladministrative hierarchy, internal-representative democracy and bargaining arrangements. In practice such principles are recombined and rebalanced, rather than one principle completely replacing all others. The challenge facing universities is: 'What university and academics for what society' (Olsen 2008c).

That is, what should be left to the discretion of partly autonomous institutions? What should be a common responsibility subject to collective decisionmaking at different levels of government? What should be commercialized and made subject to market competition and price systems? What balance should be struck among political, legal, academic, professional and commercial values and interests?

\section{PRELIMINARY CONCLUSIONS}

This essay has questioned the analytical value of 'autonomy' as detachment-from-politics and the apolitical dynamics of change assumed by NPM reformers; that is, reforms understood and justified solely in terms of their contribution to functional efficiency and economy and a good and sustainable government. In contrast, the essay has portrayed the dynamic interplay between democratic government and institutional autonomy as artifacts of partly decoupled inter-institutional processes involving struggle for power and status among interdependent and co-evolving institutions that are carriers of competing yet legitimate values, interests and behavioral logics. The problem of finding a stable equilibrium between democratic government, autonomous agencies and non-majoritarian institutions, illustrated by the cases of public administration and the public university, has been interpreted as a result of the contested nature of reforms and the limited understanding and control reformers have of the institutional configurations they intervene in.

In situations where the criteria of policy success are contested and the long-term performance of institutions are not well understood or documented, a hypothesis is that demands for more autonomy from external influence depend less on the scope of external interference than upon what interventions are perceived as inappropriate and illegitimate. Citizens and policy-makers in legitimate political orders internalize the notion that certain external interventions are appropriate and should be obeyed. The more reformers are seen as having a legitimate ordering function and as pursuing appropriate goals in accordance with appropriate procedures, the more likely it is that reforms will be acknowledged as 'self-given'; the less likely it is that interventions will be perceived as unwanted external intrusion, and the less struggle for being shielded from external influence. Likewise, the more agencies and nonmajoritarian institutions are seen to function according to predictable and socially validated principles, rules and interests, the less likely that there will be demands for reduced autonomy.

Another hypothesis is that systems tend to oscillate, rather than settle into some kind of stable equilibrium because (part of) the dynamics of change is rooted in enduring tensions within and among competing institutionalized conceptions of 'autonomy'. In a democracy the key role is the citizen, not the elected representative, and to the extent modern 
democracies continue to advance individual autonomy and creativity, democracy will be an unfinished project. In fairly homogeneous polities citizens may be relatively willing to empower a political center, but even they are unlikely to delegate total authority and power to a single institution or group of decision-makers. There are cycles of trust and identification and all actors and institutions accountable to citizens have an uncertain mandate. It will always be uncertain what authority and power elected politicians, bureaucrats, judges, diplomats, military officers, scientists, experts, professions, capitalists, bankers, business managers, religious leaders, representatives of organized interests -and the institutions they inhabit- will have.

To the extent that modern democracies continue to advance institutional differentiation and functional specialization and make use of autonomous administrative agencies and non-majoritarian institutions, there will be dynamics of change generated by tensions, collisions and co-evolution among institutions constituted on competing normative and organizational principles. Because many institutions have in-built competing principles, intra-institutional tension will also generate change. Furthermore, institutionalization of legitimate debate and opposition is an important source of innovation and change in modern democracies.

To the extent modern democracies expand European and international cooperation and integration, there will be increasing interaction between states, institutions, agencies and individuals across national borders. Actors will be more exposed to competing problem-definitions, solutions and traditions. There will be a more intensified search for 'best practice' and consistency, and dynamics of change will be generated by tensions between levels of governance and national traditions. In a multi-level and multicentered polity such as the European Union, the meaning and desirability of 'the political center' will be contested.

It is a tall order to understand the politics of such interacting dynamics and the factors driving the emergence, maintenance and erosion of confidence in institutions and actors. In particular, there is a need to understand the conditions under which nonmajoritarian institutions such as public administration and universities will be able to adapt to changing governmental policies and societal conditions without losing their institutional identities and claims to autonomy and individual freedom.

\section{ACKNOWLEDGEMENTS}

I thank Morten Egeberg, Klaus Goetz, Werner Jann, Karin Lillehei (Akasie), Per Lægreid, James G. March Paul Roness, Daniel Tarschys and two anonymous reviewers for comments to an earlier draft.

\section{REFERENCES}

Ahrne, G. and N. Brunsson eds (2004)

Regelexplosionen, Stockholm: Stockholm School of Economics.

Amaral, A., V.L. Meek and I.M. Larsen eds (2003) The Higher Education Managerial Revolution? Dordrecht: Kluwer.

Armstrong, K. A. (1998) 'Legal integration: Theorizing the legal dimension of European integration', in K.A. Armstrong and J. Shaw guest eds, Integrating Law, Journal of Common Market Studies 36 (2): 155-174.

Bach, T. and W. Jann (2008) Animals in the administrative zoo: The case of Germany's federal administration. Potsdam: Faculty of Economics and Social Sciences, University of Potsdam: working paper (to appear in Journal for Comparative Policy Analysis).

Ball, T., J. Farr and R.L. Hanson eds (1989) Political Innovation and Conceptual Change, Cambridge. Cambridge University Press.

Bendix, R. (1968) Introduction. In R. Bendix ed.: State and Society: 1-13. Boston: Little, Brown.

- (1977) Nation-Building and Citizenship, Berkeley CA: University of California Press.

Berman, H.J. (1983) Law and Revolution. The Formation of the Western Legal Tradition, Cambridge Ma: Harvard University Press.

Bladh, A. (2007) 'Institutional autonomy with increasing dependency on outside actors' Higher Education Policy 20: 243-259.

Carpenter, D.P. (2001) The Forging of Bureaucratic Autonomy. Reputations, Networks, and Policy Innovation in Executive Agencies, 1862-1928, Princeton NJ: Princeton University Press.

Christensen, J. G. (2001) ‘Bureaucratic autonomy as a political asset', in. B.G. Peters and J. Pierre eds: Politicians, Bureaucrats and Administrative Reform: 119-131. London: Routledge.

Christensen, T. (2003) 'Narrative of Norwegian governance: Elaborating the strong state', Public Administration 81 (1): 163-190.

Christensen, T. and P. Lægreid. eds (2001): New Public Management. The Transformation of Ideas and Practice, Aldershot: Ashgate.

Christensen, T. and P. Lægreid, ed. (2006a) Autonomy and Regulation. Coping with Agencies in the Modern State, Cheltenham: Edward Elgar.

- (2006b) ‘Globalization and administrative reforms: The dilemmas of combining political control and increased institutional autonomy', in A. Farazmand and J. Pinkowski eds Handbook of Globalization, Governance and Public Administration: 376-405. New York: Taylor \& Francis.

- eds (2007a) Transcending New Public Management. The Transformation of Public Sector Reforms, Aldershot: Ashgate. 
- (2007b) ‘Regulatory Agencies-The challenges of balancing agency autonomy and political control', Governance 20 (3): 499-520.

Christensen, T. and P. Lægreid (2008) 'The regulatory orthodoxy in practice', In U. Sverdrup and J. Trondal eds: The Organizational Dimension of Politics: 41-65. Bergen: Fagbokforlaget.

Christensen, T., P. Lægreid and I.M. Stigen (2006) 'Performance management and public sector reform: The Norwegian hospital reform', International Public Management Journal 9 (2): 113-139.

Cohen, M.D., March, J.G. and Olsen, J.P. (1972) A garbage can model of organizational choice, Administrative Science Quarterly 17: 1-25.

Commission (2005) Cluster 'Modernization of higher education' Brussels, Directorate-General for Education and Culture: Doc. MHE 7.

- (2006) Delivering on the modernization agenda for universities: Education, research and innovation, Brussels: COM(2006) 2008 final.

Corbett, A. (2005) Universities and the Europe of Knowledge: Ideas, Institutions and Policy Entrepreneurship in the European Union Higher Education 1955-2005, Houndmills: Palgrave Macmillan.

Council of Europe, Parliamentary Assembly (2006): Academic freedom and university autonomy. Recommendation 1762 http://assembly.coe.int/ Documents/AdoptedText/ta06/EREC1762.htm

Curtin, D. and M. Egeberg eds (2008) 'Towards a new executive order in Europe', West European Politics 41 (4), Special Issue.

Cyert, R. M. and J. G. March (1963) A Behavioral Theory of the Firm, Englewood Cliffs, NJ: PrenticeHall. 2nd ed. 1992. Oxford: Basil Blackwell.

Dahl, R.A. (1998) On Democracy, New Haven: Yale University Press.

Dixon, R., C. Hood and L. R. Jones eds (2008) `Ranking and rating public service', International Public Management Journal 11 (3), Special issue.

Döhler, M. (2002) 'Institutional choice and bureaucratic autonomy in Germany', West European Politics 25 (1): 101-124.

Dunleavy, P. and C. Hood (1994) 'From Old Public Administration to New Public Management', Public Money \& Management 14: 9-16.

Egeberg, M. (2003) 'How bureaucratic structure matters: An organizational perspective', in B. G. Peters and J. Pierre (eds) Handbook of Public Administration: 116-26. London: Sage.

- ed. (2006a) Multi-level Union Administration: The Transformation of Executive Politics in Europe, Basingstoke: Palgrave.

- (2006b) 'Balancing autonomy and accountability: Enduring tensions in the European Commission's development', in M. Egeberg ed.: Multi-level Union Administration: The Transformation of
Executive Politics in Europe: 31-50 Basingstoke: Palgrave.

Egeberg, M. and J. Trondal (2008) ‘Political leadership and bureaucratic autonomy: Effects of agencification', Oslo: Arena (manuscript).

Elias, N. (1994) [1939] The Civilizing Process, Oxford: Blackwell.

Eurydice (2008) Higher Education Governance in Europe. Policies, Structures, Funding and Academic Staff, Brussels: European Commission, Education and Culture DG.

Forvaltningskomiteen 1958: Innstilling fra Komiteen til å utrede spørsmålet om mer betryggende former for den offentlige forvaltning. Kragerø: Naper.

Foxhall, L. and A.D.E. Lewis (1996) 'Introduction', in L. Foxhall and A.D.E. Lewis eds: Greek Law In Its Political Setting. Justifications not Justice: 1-8. Oxford: Clarendon Press.

Gilardi, F. (2008) Delegation in the Regulatory State: Independent Regulatory Agencies in Western Europe, Cheltenham: Edward Elgar.

Habermas, J. (1996) Between Facts and Norms, Cambridge MA: The MIT Press.

- (1998) Does Europe need a constitution? Response to Dieter Grim. in J. Habermas, The Inclusion of the Other: Studies in Political Theory: 156-161. Ed. C. Cronin and P. de Greiff. Cambridge, MA: MIT Press.

Huntington, S.P (1968) Political Order in Changing Societies, New Haven: Yale University Press.

Jacobsen, K.D. (1964) Teknisk hjelp og politisk struktur, Oslo: Universitetsforlaget.

Joerges, C. (1996) 'Taking the law seriously: On political science and the role of law in the process of integration', European Law Journal 2 (2): 105-135.

Kaufman, H. (1954) 'Emerging conflicts in the doctrine of American Public Administration', American Political Science Review 50: 1057-1073.

Kydland, F.E. and E.C. Prescott (1977) 'Rules rather than discretion: The inconsistency of optimal plans', Journal of Political Economy 85 (3): 473-492.

Lægreid, P., S. Opedal and I.M. Stigen (2005) ‘The Norwegian hospital reform: Balancing political control and enterprise autonomy', Journal of Health Politics, Policy and Law 30 (6): 1035-72.

Lægreid, P., K. Verhoest and W. Jann guest eds (2008) 'The governance, autonomy and coordination of public sector organizations', Public Organization Review 8 (2), Special Issue.

Larsson, T. (1994) 'Cabinet ministers and parliamentary government in Sweden', in M.J. Laver and K. A. Shepsle eds, Cabinet Ministers and Parliamentary Government: 123-142. Cambridge: Cambridge University Press.

Lijphart, A. (1977) Democracy in Plural Societies. A Comparative Exploration, New Haven: Yale University Press. 
Lowi, T.J. (1979) The End of Liberalism, 2nd ed. New York: Norton.

Maassen, P. and J. P. Olsen eds (2007) University Dynamics and European Integration, Dordrecht: Springer.

MacIntyre, A. (1988) Whose Justice? Which Rationality? Notre Dame, Ind.: University of Notre Dame Press.

Magna Charta Universitatum (1988) Bologna: Bologna University (www.magna-charta.org/ pdf/mc_pdf/mc_english.pdf)

Majone G. (1996) Regulating Europe, London: Routledge.

- (1998) "Europe's "democratic deficit": The question of standards', European Law Journal 4 (1): 5-28.

- (2001) 'Two logics of delegation: agency and fiduciary relations in EU governance', European Union Politics 2 (1): 103-21.

March, J. G. (1981) 'Footnotes to organizational change', Administrative Science Quarterly 26: 563-77.

March, J. G. and J. P. Olsen (1976) Ambiguity and Choice in Organizations, Bergen: Universitetsforlaget.

- (1989) Rediscovering Institutions, The Organizational Basis of Politics. New York: Free Press.

- (1995) Democratic Governance, New York: Free Press.

- (2006a) 'The logic of appropriateness' in M. Rein, M. Moran and R.E. Goodin eds, The Oxford Handbook of Public Policy: 689-708. Oxford: Oxford University Press.

- (2006b) 'Elaborating the "New Institutionalism"', in R.A.W. Rhodes, S. Binder and B. Rockman eds: The Oxford Handbook of Political Institutions: 3-20. Oxford: Oxford University Press.

Neave, G., K. Blückert and T. Nybom eds (2006) The European Research University - An Historical Parenthesis? New York: Palgrave Macmillan.

NOU 1989: 5 (Official Norwegian Reports), En bedre organisert stat.

NOU 1999: 13, Domstolene i samfunnet.

NOU 2006: 19, Akademisk frihet: Individuelle rettigheter og institusjonelle styringsbehov.

Nybom, T. (2007) 'A rule-governed community of scholars: The Humboldt vision in the history of the European University', in P. Maassen and J.P. Olsen eds, University Dynamics and European Integration: 55-79. Dordrecht: Springer.

OECD (1991) Serving the Economy Better, Paris: Occasional Papers on Public Management.

- (1997) Report on Regulatory Reform, Paris: OECD

- (2002a) Regulatory Policies in OECD Countries. From Interventionism to Regulatory Governance, Paris. OECD.

- (2002b) Distributed Public Governance: Agencies, Authorities and Other Government Bodies, Paris: OECD.

Olsen, J.P. (1983) Organized Democracy, Oslo: Scandinavian University Press
Olsen, J.P. (2007a) Europe in Search for Political Order. An Institutional Perspective on Unity/ Diversity, Citizens/their Helpers, Democratic Design/Historical Drift, and the Co-existence of Orders, Oxford: Oxford University Press.

- (2007b) 'The institutional dynamics of the European University', in P. Maassen and J.P. Olsen eds, University Dynamics and European Integration: 25-53. Dordrecht: Springer.

- (2008a) 'The Ups and Downs of Bureaucratic Organization', Annual Review of Political Science Vol. 11: 13-37. Palo Alto CA: Annual Reviews.

- (2008b) 'Change and continuity. An institutional approach to institutions of democratic government', To appear in European Political Science Review Vol. 1, no. 12009.

- (2008c) 'What university and academics for what society?' in U. Sverdrup and J. Trondal (s.: The Organizational Dimension of Politics: 123-144. Bergen: Fagbokforlaget.

Paradeise, C., I. Bleiklie, E. Ferlie and E. Reale eds (2009) University Governance: Western European Comparative Perspectives, Dordrecht: Springer.

Pierre, J. and B.G. Peters (2000) Governance, Politics and the State, Basingstoke: Macmillan.

Pollitt, C. (2003) The Essential Public Manager, Mainhead UK: Open University Press.

Pollitt, C., C. Talbot, J. Caulfield, and A. Smullen (2004) Agencies: How Governments Do Things Through Semi-Autonomous Organizations, London: Palgrave Macmillan.

Powell, W. W. and P. J. DiMaggio eds (1991) The New Institutionalism in Organizational Analysis, Chicago: The University of Chicago Press.

Power, M. (1994) The Audit Explosion, London: Demos.

Rhodes, R.A.W. (1996) 'The new governance: Governing without government', Political Studies 44: 652-667

Roness, P., K. Verhoest, K. Rubecksen and M. MacCarthaig (2008) 'Autonomy and regulation of state agencies: Reinforcement, indifference or compensation', Public Organization Review 8 (2): 155-174.

Rothstein, B. and J. Teorell (2008) 'What is quality of government? A theory of impartial government institutions' Governance 21 (2): 165-190.

Sand, I-J. (2008) 'Reconstructing the boundaries of the market: EU law and institutions analysed through the lens of discontinuity', in H. Petersen, A-L. Kjær, H. Krunke and M. Rask Madsen eds: Paradoxes of European Legal Integration: 89-110. London: Ashgate.

Schattschneider, E.E. (1960) The Semi-Sovereign People, New York: Holt, Rinehart \& Winston.

Schillemans, T. (2008) 'Accountability in the shadow of hierarchy: The horizontal accountability of agencies' Public Organization Review 8 (2): 175-194. 
Sunstein, C.R. (1990) After the Rights Revolution. Reconceiving the Regulatory State, Cambridge Ma: Harvard University Press.

Tate, C. N. and T. Vallinder (1995) The Global Expansion of Judicial Power, New York: New York University Press.

Thatcher, M. and A. Stone-Sweet (2002) 'Delegation to independent regulatory agencies: Pressures, functions and contextual mediation', West European Politics 25 (1): 1-22.

- eds (2003) The Politics of Delegation, London: Frank Cass (also West European Politics 25 (1) 2002, Special issue).

Ullenius, C. (2005) Report from the parallel session on Institutional Autonomy and Governance, Bergen 19-20 May 2005, The Bologna process.

Verhoest, K., G. Bouckaert and B.G. Peters (2007) 'Janus-faced reorganization: specialization and coordination in four OECD countries in the period
1980-2005', International Review of Administrative Sciences 73 (3): 325-348.

Verhoest, K., B.G. Peters, G. Bouckaert and B. Verschuere (2004) 'The study of organizational autonomy: A conceptual review', Public Administration and Development 24 (2): 101-118.

Weber, M. (1978) Economy and Society. (G. Roth and C. Wittich eds). Berkeley: University of California Press.

Wockelberg, H. (2003) Den svenska förvaltningsmodellen: Parlamentarisk debatt om förvaltningens roll i styrelsesskicket, Uppsala: Uppsala University, Department of Political Science: Doctoral thesis.

World Bank (2002) Building Institutions for Markets, New York: Oxford University Press.

Yesilkagit, K. and S. van Thiel (2008) ‘Political influence and bureaucratic autonomy', Public Organization Review 8: 137-153. 